\title{
STRES DAN MEKANISME KOPING DALAM MENGHADAPI UJI KOMPETENSI PADA MAHASISWA D3 KEPERAWATAN DI FAKULTAS KESEHATAN UNIVERSITAS SAMAWA
}

\author{
Endang Setiawaty, Nila Yuliana \\ Universitas Samawa, Jalan Bypass Sering, Kerato, Unter Iwes, Kabupaten Sumbawa \\ Nusa Tenggara Barat, (0371) 625848 \\ Email: endangsetiawaty87@yahoo.com
}

\begin{abstract}
ABSTRAK
Uji kompetensi merupakan salah satu tekanan akademik yang harus dilewati mahasiswa semester akhir. Proses yang dialami mahasiswa dalam menghadapi uji kompetensi membuat mahasiswa rentan untuk mengalami stress. Mekanisme koping yang digunakan mahasiswa sangat menentukan keberhasilan mahasiswa dalam menghadapi uji kompetensi.Tujuan penelitian untuk mengetahui gambaran stress, tanda dan gejala stress, dan mekanisme koping dalam menghadapi uji kompetensi pada mahasiswa DIII Keperawatan Fakultas Kesehatan Universitas Samawa. Metode yang digunakan adalah kualitatif dengan pendekatan naratif. Sampel penelitian adalah mahasiswa semester VI Program Studi DIII Keperawatan Fakultas Kesehatan Universitas Samawa. Teknik sampling secara purposive sampling dengan kriteria mahasiswa semester VI berjumlah 15 orang, dan partisipan yang mengalami stress dalam menghadapi uji kompetensi. Teknik analisis data menggunakan model interaktif. Hasil menunjukkan gambaran stres karena factor internal yaitu motivasi rendah.Tanda dan gejala stress mahasiswa ditunjukkan seperti sulit makan, sulit tidur, dan konstipasi. Gangguan mental adanya rasa takut, cemas, gelisah, depresi, pusing, dan tidak semangat belajar.Sumber stress pada mahasiswa karena susah dalam mengatur waktu. Koping mahasiswa dalam menghadapi stress antara lain dengan carashare atau berdiskusi dengan teman atau keluarga, menghibur diri dilakukan dengan; shoping, jalan-jalan, main game, dan nonton film, mencari referensi belajar.selain itu juga berdoa, sholat dan sabar.
\end{abstract}

Kata kunci: stress; mekanisme koping; uji kompetensi; mahasiswa DIII keperawatan;

\section{STRESS AND COOPING MECHANISM IN FACING COMPETENCY TEST IN D3 NURSING STUDENTS AT FACULTY OF HEALTH, UNIVERSITY OF SAMAWA}

\begin{abstract}
Nursing Competency Test is one of the academic pressures that must be passed by final semester students. The process experienced by students in facing competency tests makes students vulnerable to experiencing stress. The coping mechanism used by students will determine the success of students in facing the competency test. The purpose of the study was to determine the description of stress, signs and symptoms of stress, and coping mechanisms in the face of competency tests on Diploma Nursing students, Faculty of Health, Samawa University. The method used qualitative with a narrative approach. The research sample was the sixth semester students of the Diploma Nursing Study Program, Faculty of Health, Samawa University. The sampling technique was purposive sampling with the criteria of 15 semester VI students, and participants who experienced stress in facing the competency test. The data analysis technique used an interactive model. The results show a picture of stress due to internal factors, namely low motivation. Signs and symptoms of student stress are shown such as difficulty eating, difficulty sleeping, and constipation. Mental disorders are such as fear, anxiety, depression, dizziness, and lack of enthusiasm for learning. The stress cause is difficult to manage time. Student coping in dealing with stress, among others, by sharing or discussing with friends or family, entertaining themselves is done by; shopping, sightseeing, playing games, and watching movies, looking for learning references. Moreover.they do spiritual ritual, such as praying.
\end{abstract}

Keywords: stress; coping mechanisms; competence test; diploma nursing students

Jurnal SMART Keperawatan is licensed under a Creative Commons Attribution-ShareAlike 4.0 International License. 


\section{LATAR BELAKANG}

Hakikatnya stres dapat terjadi pada respon fisik, psikologis dan sosial.Stres fisik atau sistemik terjadi ketika tuntutan tugas berdampak pada tubuh yang dapat mengakibatkan hilangnya kekebalan sehingga berpotensi terjadinya penyakit. Penelitian yang dilakukan oleh Anil (2010) dalam (Wahyuningsih et al., 2020) menyatakan bahwa stres dapat berpengaruh terhadap aktivitas karena stres akan membuat gangguan pada fisiologis maupun psikologis. Gejala fisiologis yang dirasakan seperti tekanan darah yang meningkat atau turun, bertambahnya berat badan, sakit perut, sakit kepala dan merasa sesak di dada ketika bernafas. Gejala psikologis yang dirasa akan yaitu ketegangan, merasa gelisah, tidak tenang, dan bosan (Sudarya et al., 2014).

Fenomena stres pada mahasiswa meningkat akhir-akhir ini, dimana mahasiswa rela untuk mengakhiri hidupnya dengan tragis, hal ini disebabkan oleh persoalan-persoalan yang terjadi dalam lingkungan perkuliahan baik yang bersumber dari persoalan ekonomi untuk biaya kuliah, dan masalah tugas akhir mahasiswa (Khaidir, 2015). Stres yang terjadi pada mahasiswa akibatnya bisa lebih fatal jika tidak datangani, karena pengalaman hidup pada usia remaja masih sedikit dibandingkan usia dewasa, sehingga mereka kesulitan untuk mencari solusi ketika menghadapi masalah.

Proses yang dialami mahasiswa dalam menghadapi uji kompetensi membuat mahasiswa rentan untuk mengalami stres. Mahasiswa yang mengalami stres dalam menghadapi uji kompetensi dapat membuat mahasiswa mengalami gangguan secara fisik, emosional, intelektual dan interpersonal. Hasil studi pendahuluan yang dilakukan Khuzaiyah et al., 2018 terhadap 10 lulusan bidan yang akan menghadapi uji kompetensi menunjukkan bahwa 8 (80\%) mengalami stress dan cemas menjelang Uji kompetensi.

Stres yang terjadi pada mahasiswa perlu dicarikan solusi penanganan lebih dini agar tidak berkembang menjadi stres yang hebat.Hal ini bisa dilakukan dengan pengenalan dan kewaspadaan tentang stres secara tepat sehingga nantinya individu menganggap stres adalah bagian dari tantangan dan bukanlah akhir dari segalanya yang tidak bisa dipecahkan. Tindakan inilah yang kemudian dikenal dengan mekanisme koping yaitu cara seseorang menyelesaikan masalah yang dihadapinya (Keliat, 2005 dalam (Krisdianto \& Mulyanti, 2015).

Mekanisme koping terbagi dalam dua yaitu koping adaptif dan koping maladaptif. Koping adaptif merupakan mekanisme koping yang mendukung fungsi integrasi belajar dan mencapai tujuan. Koping maladaptif adalah koping yang tidak mendukung fungsi integrasi, menurunkan otonomi dan cenderung menguasai lingkungan.

Menurut Stuart dan Sundeen (1995) dalam Hidayati, A. (2017)Koping adaptif seperti pengendalian diri, koping aktif, penggunaan pertolongan, perencanaan, penerimaan, koping agama, humor, dan penyusunan positif. Koping maladaptif seperti adanya penolakan dari individu itu sendiri, penggunaan zat, penggunaan dukungan emosional, ketidakberdayaan, pelepasan, dan menyalahkan diri sendiri.

\section{METODE}

Penelitian ini termasuk dalam penelitian kualitatif deskriptif dengan menggunakan pendekatan naratif. Sampel penelitian yang digunakan peneliti adalah mahasiswa semester VI Program Studi D3 Keperawatan Fakultas Kesehatan Universitas Samawa. Teknik sampling yang digunakan yaitu purposive sampling dengan kriteria mahasiswa semester VI berjumlah 15 orang, dan mahasiswa yang mengalami stress ringan, sedang, berat, dan sangat berat. Teknik analisis data menggunakan model interaktif. Sebelum penelitian dilakukan, peneliti sudah melakukan uji etik (ethical clearance) di Komisi Etik Penelitian Kesehatan Universitas Mataram dengan nomor 180/UN18.F7/ETIK/2020.

\section{HASIL}

\section{Stress di kalangan mahasiswa}

Uji Kompetensi diwajibkan sebagai bagian dari persyaratan pendidikan akademis di Perguruan Tinggi karena Uji Kompetensi digunakan 
sebagai salah satu prasyarat bagi mahasiswa untuk memperoleh sertifikat surat tanda registrasi perawat sebagai Ahli madya keperawatan. Mahasiswa yang menghadapi Uji Kompetensi dituntut untuk dapat menyesuaikan diri dengan proses belajar yang ada dalammenghadapi Uji Kompetensi. Dimana mahasiswa diharapkan menghasilkan nilai yang memuaskan dan kompeten.

Proses dalam menghadapi uji kompetensi dapat mengakibatkan mahasiswa menjadi stress. Penyebab stress biasanya disebut sumber stress (stressor) yang terdiri dari dua jenis antara lain sumber internal dan eksternal. Tidak sedikit mahasiswa berkeluh kesah di saat mereka menghadapi uji kompetensi.

Hasil analisa faktor yang mempengaruhi stress adalah karena motivasi yang rendah.

...kalau dari dalam diri...ya sebenarnya motivasi saya ya!...ini ya!...pingin cepat selesai..pingin cepat mendapatkan sebuah gelar...

...motivasi dari luar dari dalam..mungkin dari dalam diri itu..ada ya!.. jelas..mampu lulus uji kompetensi

\section{Tanda dan gejala stres pada mahasiswa}

Tanda dan gejala stres pada mahasiswa dalam menghadapi Uji Kompetensi yaitu terjadi gangguan fisik dan gangguan mental. Gangguan fisik seperti sulit makan, sulit tidur, dan konstipasi. Sedangkan gangguan mental seperti rasa takut, cemas, gelisah, depresi, pusing, dan tidak semangat belajar. Hal ini sesuai dengan hasil wawancara sebagai berikut:

...biasanya sulit untuk makan...sulit tidur...biasanya malah konstipasi...

... setiap malam tu gak bisa tidur..benerbener tersiksa..bolak-balik..bolakbalik...susah tidur..insomnianya kumat..setelah itu..ehm disamping gak bisa tidur..maag juga kambuh dan perih juga kan..udah sih itu aja...(R3).

...campur aduk sih

mbak..e..bingung...tegang...cemas...ya

seperti itu!...(I2)... ...kalau saya kadang-kadang

nangis..pasrah juga.....marah, nangis,...(R1).

...terus dampak yang lain mungkin ne tangan aja udah berkeringat gak jelas (sambil menunjukkan tangannya)..tegang ini...konstrenstrasi buyar semua....(R5).

\section{Sumber Stres didapatkan mahasiswa stress karena susah dalam mengatur waktu (Time management)}

Tidak semua mahasiswa mampu mengatur waktunya dengan baik.Pengaturan waktu ini menjadi salah satu sumber stres internal dalam diri mahasiswa yang sedang menghadapi Uji Kompetensi. Mahasiswa yang sibuk mengerjakan hal lain akan menemukan kesulitan bila mereka tidak dapat mengatur waktunya dengan baik. Karena ada saat dimana mereka harus mengerjakan berbagai macam hal, seperti tugas penyusunan karya tulis ilmiah (KTI) dan menghadapi Uji Kompetensi.

Mahasiswa semester VI Fakultas kesehatan Universitas Samawa ketika menjalani proses menghadapi uji kompetensi mengalami kendala dalam mengatur waktu dikarenakan bersamaan dengan tugas-tugas kuliah yang lain. Hal ini seperti yang diungkapkan responden sebagai berikut:

... kalau dari dalam diri saya sih!...sulitnya membagi waktu tu lo!... kalau dari dalam diri saya...

...kalau dari dalam diri saya sendiri itu saya manajemen waktunya tu kurang bagus..saya kurang disiplin dengan jadwal-jadwal yang sudah saya buat..itu salah satu kendala...

Hasil wawancara diatas dapat diketahui bahwa dalam proses menghadapi Uji Kompetensi, tidak semua mahasiswa mampu mengatur waktu dengan baik. Pengaturan waktu ini menjadi salah satu sumber stres internal dari mahasiswa yang sedang dalam proses menghadapi Uji Kompetensi. 
Mekanisme Koping di kalangan mahasiswa. Bentuk-bentuk strategi koping

Bentuk-bentuk koping yang digunakan mahasiswa dalam proses menghadapi Uji Kompetensi adalah Mahasiswa dalam menghadapi stres dengan carashare. Hal ini seperti yang diungkapkan responden sebagai berikut :

...kalau saya pertama kita share sama orang tua atau teman...cerita sama ibu atau teman kendala-kendala yang kita hadapi sampai mengakibatkan stress...

Selain share atau berdiskusi untuk menghadapi stres mahasiswa dalam proses menghadapi uji kompetensi yaitu dengan cara hiburan. Hal ini seperti yang diungkapkan beberapa responden sebagai berikut:

...ya biasanya main ma temanteman....menyalurkan hobi kayak futsal kayak gitu...biasanya seperti itu....ehm....main game...

...terus kita mungkin pergi shoping..pergi jalan ama teman..nonton TV..main game....

Hasil wawancara diatas dapat diketahui bahwa untuk menghadapi stress selain dengan cara share, dalam menangani stress yang dialami mahasiswa, mahasiswa juga melakukan hal-hal yang bersifat menghibur diri seperti bermain futsal, main game, shoping, jalan-jalan, dan nonton tv, sehingga dengan cara ini mereka dapat mengurangi stress yang dialami.

Koping lain yang digunakan menghadapi stress oleh mahasiswa yaitu dengan cara berdoa, shalat dan sabar dalam mengatasi stress yang dialami. Hal ini seperti yang diungkapkan salah satu responden sebagai berikut:

...biasanya setelah itu ee..lebih ke berdoa sih shalat kayak gitu....

Hasil wawancara diatas dapat diketahui bahwa koping dengan cara berdoa, shalat dan sabar juga dapat mengurangi beban stress yang dialami mahasiswa yang sedang dalam proses menghadapi Uji Kompetensi.

\section{PEMBAHASAN}

Berdasarkan hasil penelitian didapatkan stress di kalangan mahasiswa yang diwawancarai faktor-faktor yang mempengaruhi stress adalah motivasi yang rendah. Menurut B. Uno (2011) berpendapat bahwa motivasi belajar adalah dorongan internal dan eksternal pada diri seseorang yang sedang belajar untuk mengadakan perubahan tingkah laku, pada umumnya dengan beberapa indikator atau unsur yang mendukung. Hal ini mempunyai peranan besar dalam keberhasilan seseorang dalam belajar. Motivasi belajar pada mahasiswa sangat berpengaruh terhadap hasil akademik itu sendiri (Pratama \& Prihatiningsih, 2014).

Motivasi berprestasi menjadi hal yang sangat penting dalam mengatasi dan mencegah terjadinya suatu kegagagalan tersebut. Dimana seorang mahasiswa yang memiliki motivasi berprestasi yang tinggi akan cenderung berusaha untuk memanajemen waktunya dengan baik dalam menentukan suatu tujuan yang telah di tetapkan sebelumnya sehingga kegagalan yang kan terjadi dapat di minimalisir oleh mahasiswa tersebut (Sagita, dkk, 2017).

Tanda dan gejala stres pada mahasiswa menunjukkan bahwa mahasiswa dalam menghadapi uji kompetensi mengalami tanda dan gejala seperti rasa takut, cemas, gelisah, depresi, pusing, dan tidak semangat belajar.Tanda-tanda stress ini sesuai dengan pendapat dari Rasmun, 2004 dalam penelitian (Kurniati \& Mamnu'ah, 2014) tanda-tanda stress yang dapat ditimbulkan seperti sakit kepala, pusing, gangguan pencernaan dan pola makan, cemas, sedih, susah berkonsentrasi, daya ingat menurun, pikiran kacau.

Sumber stress/stressor pada mahasiswa karena susah dalam mengatur waktu (Time management). Dari hasil wawancara dengan mahasiswa dapat diketahui bahwa dalam proses menghadapi uji kompetensi, tidak semua mahasiswa mampu mengatur waktu dengan baik. Pengaturan waktu ini menjadi salah satu sumber stres internal dari mahasiswa dalam proses menghadapi uji kompetensi. 
Mahasiswa yang sibuk mengerjakan hal lain seperti tugas-tugas kuliah dari kampus, dimana mereka akan mengalami kesulitan dalam mengatur waktunya dengan baik. Hal ini yang dapat memicu timbulnya stress sebagaimana yang tercantum dalam penelitian (Kholidah \& Alsa, 2012) sumber masalah yang membuat mahasiswa mengalami stres salah satunya disebabkan karena manajemen waktu yang kurang tepat.

Mekanisme koping yang digunakan mahasiswa dalam proses menghadapi uji kompetensi adalah dengan cara share, hiburan diri, dan beribadah. Share adalah cara seseorang inidivu untuk mengatasi stres yang dihadapi dengan cara berdiskusi dengan keluarga ataupun teman.Begitu pula yang dilakukan mahasiswa semester VI Prodi D3 Keperawatan Fakultas Kesehatan Universitas Samawa dalam mengatasi stress yang dihadapi dalam menghadapi uji kompetensi. Menurut penelitian (Husna, 2012) terdapat responden yang juga sering berbagi cerita dengan teman-temannya dengan tujuan dapat mengurangi beban pikiran yang sedang mereka alami.

Selain mekanisme koping dengan carashare, mahasiswa juga menghadapi stress dalam menghadapi uji kompetensi dengan cara hiburan atau menghibur diri. Menghibur diri dengan cara bermain futsal, main game, shoping, jalan-jalan, dan nonton tv. Hal ini didukung dengan hasil penelitian yang dilakukan oleh (Syapitri \& Hutajulu, 2020) tentang faktor-faktor yang berpengaruh terhadap kelulusan uji kompetensi mahasiswa dan dapat dijadikan acuan yaitu kepemilikan referensi, pemahaman blueprint soal, keikutsertaan bimbingan belajar, dan keikutsertaan try out.

\section{KESIMPULAN DAN SARAN}

Stres pada mahasiswa dalam proses menghadapi Uji Kompetensi disebabkan karena motivasiyang rendah. Tanda dan gejala yang dirasakan mahasiswa bermula dari adanya gangguan fisik seperti sulit makan, sulit tidur, dan konstipasi.Sedangkan gangguan mental seperti rasa takut, cemas, gelisah, depresi, pusing, dan tidak semangat belajar. Timbulnya stress pada mahasiswa dalam menghadapi Uji Kompetensi ini bersumber karena susah dalam mengatur waktu yang dapat menghambat jalannya proses menghadapi Uji Kompetensi.

Mekanisme koping mahasiswa dalam menghadapi Uji Kompetensi bahwa terdapat beberapa hal yang menjadi bentuk mekanisme koping mahasiswa dalam proses menghadapi uji kompetensi yaitu dengan cara share,menghibur diri dengan jalan-jalan, mencari referensi materi uji kompetensi, mengikuti bimbingan uji kompetensi dari kampus, shalat dan berdoa.

Hasil penelitian ini semoga dapat menjadi bahan masukan kepada pihak kampus hendaknya dapat memperhatikan dan mengatasi stress yang dialami mahasiswa khususnya semester akhir yang sedang menghadapi proses uji kompetensi.

\section{REFERENSI}

Agung Krisdianto, M., \& Mulyanti, M. (2016). Mekanisme Koping dengan Tingkat Depresi pada Mahasiswa Tingkat Akhir. Jurnal Ners Dan Kebidanan Indonesia, 3(2), 71. https://doi.org/10.21927/jnki.2015.3(2).71-76

Auliya Hidayati. (2017). HUBUNGAN HEALTH LOCUS OF CONTROL DENGAN Digital Digital Repository Repository Universitas Universitas Jember Jember.

B. Uno. (2011). Motivasi dan Pengukurannya. Jakarta: Bumi Aksara

Husna, C. (2012). Mekanisme Koping Pada Pasien Dm Tipe li Dengan Gangren Diabetik Di Poliklinik Endokrin Rsudza Banda Aceh. Idea Nursing Journal, 3(1), 42-49.

Khaidir, T. A. (2015). 8 Bulan, 5 Mahasiswa di Medan Bunuh Diri. https://medan.tribunnews.com/2015/05/19/8bulan-5-mahasiswa-di-medan-bunuh-diri

Kholidah, E., \& Alsa, a. (2012). Berpikir Positif untuk Menurunkan Stres Psikologis. Jurnal Psikologi, 39(1), 67-75. http://jurnal.psikologi.ugm.ac.id/index.php/fpsi larticle/view/180

Khuzaiyah, S., Chabibah, N., \& Khanifah, M. (2018). Manfaat Hipnoterapi Spiritual Dalam Menurunkan Tingkat Kecemasan Mahasiswa Menghadapi Uji Kompetensi Bidan Indonesia 
(Ukbi). Jurnal SMART Kebidanan, 5(1), 47. https://doi.org/10.34310/sjkb.v5i1.151

Kurniati, T., \& Mamnu'ah, M. A. (2014). Hubungan Prokrastinasi Akademik dengan Tingkat Stres pada Mahasiswa DIV Bidan Pendidik Anvullen di Stikes' Aisyiyah Yogyakarta Tahun 2014 (Doctoral dissertation, STIKES'Aisyiyah Yogyakarta).

Pratama, M. R., \& Prihatiningsih, D. (2014). Hubungan motivasi akademi dengan tingkat Stres akademi mahasiswa keperawatan semester VI Stikes'Aisyiyah Yogyakarta. Naskah Publikasi STIKES 'Aisyiyah Yogyakarta, 1-16.

Sagita, D. D., Daharnis, D., \& Syahniar, S. (2017). Abstrak. 1, 43-52.
Sudarya, I. W., Bagia, I. W., \& Suwendra, I. W. (2014). Analisis faktor-faktor yang mempengaruhi stres pada mahasiswa dalam penyusunan skripsi jurusan manajemen undiksha angkatan 2009. E-Journal Bisma Universitas Pendidikan Ganesha Jurusan Manajemen, 2(1), 1-10.

Syapitri, H., \& Hutajulu, J. (2020). Strategi Mahasiswa Profesi Ners Dalam Menghadapi Uji Kompetensi Ners Di Usm Indonesia. Jurnal Surya Muda, 2(2), 76-84. https://doi.org/10.38102/jsm.v2i2.66

Wahyuningsih et al. (2020). Issn 2715 - 6060. 1(2), 80-87. 